\title{
The Use of Contextual Teaching and Learning Model to Increase Student's Activeness and Learning Achievement in Science Learning
}

\author{
Nurul Hidayati ${ }^{1}$, Y. Suyitno ${ }^{2}$, Rasito ${ }^{3}$ \\ \{ $\underline{\text { nurulhidayati271980@gmail.com }}$, suyitno.y@gmail.com²,$\underline{\text { akhi.rasito@gmail.com }}$ \} \\ ${ }^{1,2,3}$ Universitas Muhammadiyah Purwokerto
}

\begin{abstract}
Teacher has a very strategic role and position. So, they must be able to plan and develop attractive, creative, and dynamic teaching activities The purpose of this research is to increase student's activeness and learning achievement through Contextual Teaching and Learning model in Science learning. This type of research is Classroom Action Research with two cycles. Each cycle includes planning, implementing actions, observing, reflecting. The research results in the first cycle, as many as 13 students completed the KKM with a rate of $46.42 \%$. In the second cycle, students who completed the KKM increased to 26 children, with a rate of $92.86 \%$. Student activeness in science subject content through the Contextual Teaching and Learning learning model reached $89.29 \%$ with 25 students in the "excellent" activeness category. Based on the results of this research show that the use of Contextual Teaching and Learning model can increase student's activeness and learning achievement in Science learning.
\end{abstract}

Keywords: Contextual teaching, and learning models, activeness, science learning, elementary school

\section{Introduction}

According to Purwanto, learning is a process within individuals who interact with the environment to change their behavior [1]. Learning is a mental/ psychic activity that occurs in active interaction with the environment, which produces changes in knowledge, skills and attitudes. These educational goals can be achieved if the teacher can realize a teaching and learning process properly.

In the teaching and learning process, a teacher has a very strategic role and position. The teacher must be able to plan and develop attractive, creative, and dynamic teaching activities, so that the teaching and learning process in the classroom is fun for students and the learning achievement achieved will be optimal. But in reality, there are still problems about the low learning activeness in students. This can be known through observation which is done on student's attitude during learning activities. The impact of the weak of student's self-confidence during the learning process can be shown by the emergence of student's attitude who do not dare to do something so that students cannot explore their ability [2].

Based on the results of observations made during science learning in class $\mathrm{V}$, which amounted to 28 students, the activeness and learning outcomes of students' science was still low. This can be seen from the indicators of activity: 1) students who are active in discussing as many as 8 students $(28.57 \%), 2)$ students who ask questions as many as 5 students $(17.85 \%), 3$ ) students who present answers to practice questions as many as 7 students $(25.00 \%)$. The low learning outcomes are indicated by the minimum number of students who meet the KKM with 
a minimum score of 70 as many as 12 students (43\%) while those who meet the KKM are 16 students $(57 \%)$.

The low activity and achievement of student learning can be caused by the implementing of learning so far, still using conventional methods. It is predicted to be the cause of the low student achievement. One way to do something different in teaching is to use a learning model. By utilizing a model learning, the implementation of learning will be more systematic. In the learning model, there is a conceptual framework that is used as a guide in carrying out activities, so that learning takes place well [3]. The learning improvement that will be done by researcher is planning the use of learning models that are expected to be more attractive and can increase students' understanding, so that there is an increase in student achievement.

Based on these problems, the researchers wanted to increase the activeness and achievement of learning science through the Contextual Teaching Learning (CTL) learning model. Contextual Teaching and Learning (CTL) is a learning concept that helps teachers link learning material with real-world situations and encourages students to make connections between their knowledge and its application in everyday life. Knowledge and skills are received from students' efforts to construct their new knowledge and skills as they learn [4]. Contextual Teaching and Learning (CTL) is a learning approach that emphasizes student involvement in finding the material they are learning and connecting and applying it in their lives. Thus, the role of students in Contextual Teaching and Learning (CTL) learning is as a learner subject who finds and constructs the concepts they learn independently.

The Contextual Teaching and Learning (CTL) model are chosen because it has advantages, namely (1) students are actively involved in the learning process, (2) students learn from friends through group work, discussion, and correcting each other, (3) learning is associated with reallife or simulated problems, (4) behavior is built on self-awareness, (5) skills are developed based on understanding, (6) students use critical thinking skills, are fully involved in making the learning process effective and take responsibility for the occurrence of learning effectively [5].

Based on the description of the background, the researcher will do research through Classroom Action Research (PTK) entitled "The Use of Contextual Teaching and Learning Model to Increase Student's Activeness and Learning Achievement in Science Learning in the fifth Grade of Elementary School."

\section{Research Methods}

The approach in this research is Classroom Action Research. This Research was oriented towards improving the quality of learning. The place used for the research was SD Negeri Glagah, Umbulharjo District, Yogyakarta City. The research subjects were 28 students of $5^{\text {th }}$ grade consisting of 14 girls and 14 boys. In this classroom action research, the research object is the learning model Contextual Teaching and Learning (CTL), activeness, and learning achievement in Science. According to the orientation, this type of research has the advantage of improving and improving the quality of the process and learning outcomes. To get the correct data, observation, documentation, and test methods were used. In this study, researchers used construct validity, also known as logical validity. Validity is a measure that shows the levels of validity or validity of an instrument [6]. This validity aims to obtain actual data in the field. The validity test used in this study is constructed validity. According to Sugiyono, construct validity is validity using the opinion of experts (expert judgment) [7]. Instrument validation was done by researcher to get responses, comments, suggestions, criticism, and valuation from the experts on the instrument's worthiness and quality which is used in the research. Instrument validation was carried out by the research supervisor. The valuation and the responses obtained from the experts were used by the researcher to revise the instrument developed by the researcher. 
This research is discussed collaboratively with colleagues to maintain validity and pay attention to the following matters: 1 ) the observers make observations the entire sequence of events that occur in class; 2) clear objectives, time limits, and observation signs; 3 ) the results of observations were recorded entirely and carefully; and 4) observations must be made objectively. This Classroom Action Research is said to be successful, if there is an increase in student activity in science subject content through the Contextual Teaching and Learning (CTL) learning model in class V SD Negeri Glagah, namely: 1) active students have at least reached $75 \%$ with the category "good "Of the total students, namely 21 children; 2) the implementation of learning through the Contextual Teaching and Learning (CTL) model if the teacher's activities are at least in the "good" category; 3) there is an increase in student achievement in science subject content through the Contextual Teaching and Learning (CTL) learning model in class V SD Negeri Glagah has reached at least $75 \%$ of the total number of students who have met KKM 70.

The Contextual Teaching and Learning (CTL) learning model allows students to more easily understand the teaching material presented. The contextual learning model is carried out by linking learning with everyday's life, so that students have no difficulty understanding the content of learning. The Contextual Teaching and Learning (CTL) learning model is one model that is considered suitable to be applied to high-grade elementary school students. This learning model begins by: (1) the teacher provides motivation, focus attention, delivery of competencies, objectives, and directing instructions; (2) carry out exploration, inquiry, and generalization activities as far as possible; (3) develop students' curiosity by asking questions; (4) forming learning societies or studying in groups; (5) presenting the model as an example of learning; (6) constructing concepts, analysis, and synthesis; (7) reflecting by reviewing and following up at the end of the meeting. Furthermore, the teacher carries out an authentic assessment during the process and after learning objectively, and various ways were done to get results that genuinely represent student competencies.

This study, we are using a model conducted by Kemmis and Mc Taggart, which is a development of Kurt Lewin's model, a model based on the concept that action research consists of four main components, as shown in Figure 2 [8].

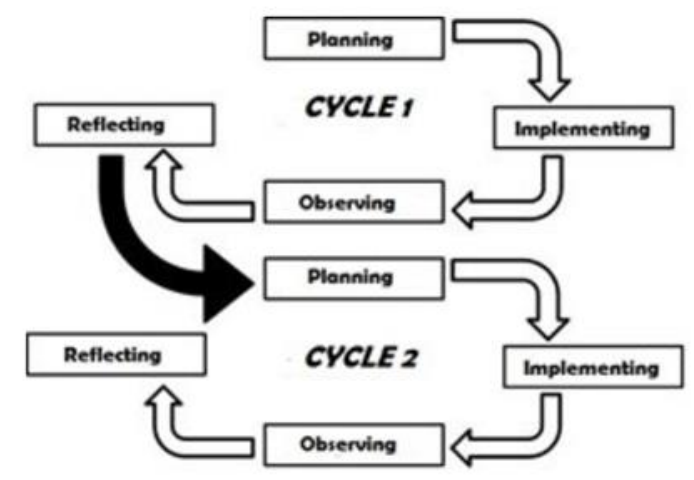

Figure 1. The Basic Model of Kurt Lewin's Classroom Action Research 


\section{Results and Discussion}

This classroom action research begins with the observation of learning in class V SD Negeri Glagah. It is known that there are still many students who still get low science scores. It can be seen from the first and second test scores are still far from the KKM (70). In the first daily test, the researcher saw still students who scored 52, 32, 42, 45, 56, 60, and 62. Of the 28 children, only 11 students reached the KKM, and the remaining 17 students had not reached the KKM. As for the second daily test, only 13 students earned the KKM, and 15 other children had not reached the KKM.

Based on the results of further observations, it was found that the cause of this problem was the inaccurate selection of a learning approach, namely still using a teacher-centered learning approach. It can be seen from the lecture method with a little students' involvement and the assignment method. The use of these two methods were very visible from the interaction of teacher and students which only run in one direction, from teacher to student. Therefore, this study was conducted to improve science learning achievement using the CTL (Contextual Teaching and Learning) learning model.

This Classroom Action Research (CAR) was done in two cycles because after cycle II, Science learning achievement had reached the targeted success indicator, which was more than or equal to $75 \%$ of students achieving the KKM set by the school, namely 70 . So after cycle II, this study was stopped.

Observation activities carried out during science learning resulted in data that Science learning with the CTL (Contextual Teaching and Learning) approach in class V SD Negeri Glagah had reached $89.58 \%$ or 3.58 in the excellent category. This has exceeded the target indicators of research success, that is, more than $80 \%$ performed or scored in the excellent variety $(3.25 \leq \mathrm{x} \leq 4.00)$. This show the teacher and students have implemented the CTL (Contextual Teaching and Learning) approach properly according to lesson plan that have been arranged.

Based on the result of the first cycle of knowledge test, seems that there are 13 students $(46.42 \%$ ) have passed the KKM (value $\geq 70$ ), while 15 students have not passed the KKM (value $<70$ ) with a rate of $53.58 \%$. The average of cycle I is 69.64 . The lowest score obtained by students was 50 , and the highest score obtained by students was 86 .

Student activity in science subject content on various diseases that affect human digestive organs, and maintaining the health of human digestive organs through the CTL (Contextual Teaching and Learning) learning model in class V SD Negeri Glagah reached $67.86 \%$ with 19 "good" activeness categories students. Reflection activities in this first cycle, carried out by researchers with colleagues to evaluate the actions that have been done. The evaluated things are considered are related to the successes and obstacles that arise during the implementation of the step in cycle I. In addition, this reflection activity is also done to find solutions to problems that occur in processI as a material for improvement in cycle II.

In this cycle I classroom action research, the successes that have been achieved are as follows: The teacher has been able to apply the CTL (Contextual Teaching and Learning) approach well to the science subject matter, although there are still some shortcomings. It can be seen from the percentage of the implementing of the CTL (Contextual Teaching and Learning) approach, which averaged $89.58 \%$.

Based on the knowledge test, it can be concluded that the Science knowledge of the V grade students of SD Negeri Glagah has not reached the specified success criteria, even though the implementation of the CTL (Contextual Teaching and Learning) approach in science learning has exceeded the established success criteria. Therefore, this research was continued to cycle II with several improvements to overcome the existing obstacles. 
As for the results of observations made by researchers, the obstacles that arise during the implementation of the action cycle I am as follows: students pay less attention to the teacher's explanation. This can be seen from students who chat, daydream, and play alone when the teacher explains the subject matter. This can be seen from only 19 active students $(67.86 \%)$. At the same time, the target will be met if the students' activeness is at least $75 \%$ or as many as 21 children, many students are reluctant to record the main points of the subject matter, the teacher is still focused on some students so that not all students pay attention to the teacher's explanation.

Seeing the problems that exist in cycle I, it is necessary to improve in cycle II so that students' science learning achievement increase. Therefore, the required modifications are: 1) involving students in the science learning process, such as students being invited to discuss when the teacher explains the subject matter; 2) students are asked to record the main points of the subject matter; 3 ) the teacher pays attention to all students in explaining the subject matter.

Table 1. Comparison of students' Science Knowledge Test Results from Cycle I to Cycle II

\begin{tabular}{lcc}
\hline \multicolumn{1}{c}{ Success Criteria } & Rate (Cycle I) & Rate (Cycle II) \\
\hline Completed KKM $(\geq 70)$ & 46.42 & 92.86 \\
Not complete KKM $(<70)$ & 53.58 & 7,14 \\
Average score & 69.64 & 89.43 \\
\hline
\end{tabular}

Based on the table above, it can be seen that students' science knowledge tests have increased from cycle I to cycle II. In the first cycle, the students who have not passed the KKM were 15 students $(53.58 \%)$ and in the second cycle were two students $(7.14 \%)$. The average class value increased from 69.64 in the first cycle to 89.43 in the second cycle. If this was compared with the indicators of research success, the results in the second cycle have reached the hands of research success, namely $75 \%$ of students completed the KKM, which is a total of 26 children $(92.86 \%)$.

Active students in science subject matter various diseases that affect the human digestive organs and how to maintain the health of human digestive organs through the CTL (Contextual Teaching and Learning) learning model in class V SD Negeri Glagah reached $89.29 \%$ with the "excellent" activity category as many as 25 students.

As for the second cycle of Classroom Action Research, the successes that have been achieved are as follows: 1) students' knowledge of science has increased and has reached the specified success indicators, namely $\geq 75 \%$ of students complete KKM (70); 2) the teacher has been able to apply the CTL approach very well to the science subject matter, it can be seen from the percentage of implementation of the the model which reaches $95.83 \%$ and has exceeded the established success indicators $>80 \%$ is carried out; 3 ) student activity in science subject content on various diseases that affect human digestive organs and how to maintain the health of human digestive organs through the CTL learning model in class V SD Negeri Glagah reached 89.29\% with the category of "excellent" activeness as much as 25 students.

Based on the explanation above, it can be concluded that the knowledge and feasibility of the CTL model in cycle II research are by the established success indicators and is said to be successful. Therefore, the implementation of the classroom action research plot was stopped in this second cycle.

Based on the description of the research results previously described, it can be seen that the implementation of science learning using the CTL model has improved science learning achievement. This is indicated by the increase in students' knowledge tests from cycle I to cycle II. In the first cycle, 13 students have completed the KKM (amounting to $46.42 \%$ ), and 15 
students have not completed the KKM (amounting to 53.58\%). In cycle II, as many as 26 students completed KKM (increased to $92.86 \%$ ), and two students had not completed KKM (amounted to $7.14 \%$ ).

The CTL model in Science learning in the V class of SD Negeri Glagah was done by implementing seven components which include constructivism, inquiry, questioning, learning society, modeling, reflection, and accurate assessment. The implementation of these seven components is carried out with the help of contextual worksheet. At the beginning of the lesson, the teacher begins the study with perceptions and motivation to link the content of science lessons with students' daily lives. This association is done to build student learning motivation at the beginning of learning. Furthermore, the teacher explained the material by doing question and answer with students, which was the component of questioning. In explaining this material, the teacher involved the students in doing interview with school members (modeling).

After that, to know the student's learning progress, the teacher carried out authentic assessment either in the form of written test or an oral examination, as the students were asked directly. As for the contructivism component, inquiry, and the learning society were done by asking some questions about Science to the students. Then the teacher formed a study group consisting of 4 students. Through the formation of this study group, students will work together and learn to solve existing problems.

After all, groups are formed, through worksheet, students carry out a process of problem identification and data collection to solve these problems by collecting information through teaching materials, PowerPoint media, student books, the internet, or other book sources, as well as survey activities by interviewing residents school based on experiences in everyday life. As long as students carry out the process, the teacher also walks around the class to help groups with difficulties. When finished, each group presented the results of their discussion, followed by talks on solving problems.

The reflection component is carried out at the end of each lesson utilizing the teacher providing opportunities for students to recall what they have learned. This reflection activity is carried out by the teacher and the students to conclude the lesson. At the end of the lesson, the teacher carries out an authentic assessment (real assessment) in the form of a written test to measure student learning achievement.

Applying the CTL approach in science learning in class V SD Negeri Glagah has effectively increased science knowledge. It is because the use of the this model in science learning can improve student activity in seeking answers to problems encountered in an interactive, safe, comfortable, and conducive manner, and provide opportunities for students to try to check, find, and conclude by themselves logically, critically, analytically, and systematically [9]. Therefore, based on the discussion, it can be concluded that the application of the CTL model in science learning can increase the activeness and learning achievement of students in class V SD Negeri Glagah and the action hypothesis proposed in this study is accepted.

\section{Conclusion}

Based on the results of research and discussion, it can be concluded that the application of the CTL approach in science learning can increase the activeness and learning achievement of students in class V SD Negeri Glagah. Based on the result of the knowledge test of Science, CTL (Contextual Teaching and Learning) in Science learning in cycle I, there were 13 students that have passed the KKM with a rate of $46.42 \%$. In the second cycle, students who completed the KKM increased to 26 children with a rate of $92.86 \%$. The average value of the class also increased from 69.64 in the first cycle, then rose to 89.43 in the second cycle. Student activity 
in science subject content on various diseases that affect human digestive organs and how to maintain the health of human digestive organs through the CTL (Contextual Teaching and Learning) learning model in class V SD Negeri Glagah reached $89.29 \%$ with the "excellent" activeness category, namely as many as 25 students.

\section{References}

[1] Purwanto. Teaching Evaluation. Bandung: PT Remaja Rosdakarya, 2012. Pg. 39.

[2] Nirmala SD. Kemampuan Berpikir Kritis Siswa Kelas IV Se-Gugus 2 Purwasari Dalam Membaca Pemahaman Melalui Model Fives Dan Model Guided Reading. Dinamika Jurnal Ilmiah Pendidikan Dasar. 2019 Feb 12;10(2).

[3] Redhiana D. Pengembangan Kurikulum Pada Aspek Ilmu Pengetahuan dan Teknologi yang Berbasis Lingkungan Hidup Melalui Pendekatan Saintifik di Sekolah Dasar. Dinamika Jurnal Ilmiah Pendidikan Dasar. 2014;6(2).

[4] Muslich, Masnur. KTSP Competency-Based and Contextual Learning. Malang: Earth Literacy, 2007. Pg. 41.

[5] Agustiya F, Sunarso A, Haryani S. Influence of ctl model by using monopoly game media to the students motivation and science learning outcomes. Journal of Primary Education. 2017 Sep 11;6(2):114-9.

[6] Arikunto, S. Research Procedure A Practical Approach. Jakarta: Rineka Cipta, 2006. Pg. 168.

[7] Sugiyono. Quantitative Research Methods, Qualitative and R \& D. Bandung: Alfabeta, 2007. Pg. 177.

[8] Arikunto, S., Suhardjono, Supardi. Classroom action research. Jakarta: PT Bumi Aksara, 2008. Pg. 16-22.

[9] Muhsan J, Letasado RM. Improving Students' Science Process Skills for Material of Forces Through the Contextual Teaching Learning Model (CTL) in Elementary School. InProceeding of the 5th Progressive and Fun Education International Conference (PFEIC 2020) 2020 Oct 15 (Vol. 479, p. 8487). 